\title{
Filosofia e Psicologia: o pensamento fenomenológico existencial de Karl Jaspers*
}

\author{
Márcia Maria da Silva \\ Universidade Federal de São João del-Rei - UFSJ
}

CARVALHO, J.M. de. Filosofia e Psicologia: o pensamento fenomenológico existencial de Karl Jaspers. Lisboa: Imprensa Nacional - Casa da Moeda, 2006.

E m seu livro, José Maurício de Carvalho analisa o pensamento de Karl Jaspers dando ênfase ao uso que ele faz do método fenomenológico. $\mathrm{O}$ autor examina a visão que o filósofo tem do movimento existencialista, também apresenta a idéia que ele tece da realidade, além de falar da relação que há entre a Filosofia e Psicologia que elaborou. A partir destas questões, o autor apontará as contribuições do filósofo para o pensamento filosófico contemporâneo, observando que para ele a visão fenomenológica - existencial não se limita a uma atitude contemporânea e passageira.

No primeiro capítulo, encontra-se a avaliação de Jaspers do movimento existencialista. De início estão os temas marcantes na meditação filosófica de Karl Jaspers. Para Carvalho, Jaspers cria explicações para a realidade que ajudam seus contemporâneos a elaborar um sentido para o que existe e para a vida do homem. A sociedade humana procura um sentido para seu destino e para tudo o que faz parte dele. Sabe-se que muitas questões que os filósofos enfrentam, a singularidade existencial, por exemplo, mudam de acordo com as transformações observadas na vida social. Contudo, há problemas que permanecem merecendo exame constante das diferentes gerações desde a Grécia antiga, como a indagação sobre a realidade. Jaspers elabora sua meditação filosófica à partir da relação que o homem tem com as coisas. Ele preserva da filosofia do esclarecimento, especificamente do criticismo de Emmanuel Kant, a defesa da racionalidade. Parece-lhe a defesa da racionalidade uma conquista incontornável da consciência. Apesar de não se considerar um existencialista, é reconhecido por muitos comentadores respeitados como importante representante do movimento. De acordo com o filósofo, o existencialismo é uma corrente que coloca o problema da realidade na ótica do existente. Assim como também fizeram outros filósofos do seu tempo, Jaspers elaborou uma teoria da realidade, com as referências da fenomenologia. Ele avalia que a partir dos estudos fenomenológicos já não se pode falar de uma estrutura definitiva e imutável do real.

${ }^{1}$ Acadêmica do Departamento de Filosofia, Universidade Federal de São João del-Rei, Praça Frei Orlando, 170, Centro, São João del-Rei, MG, 36307-352 (dfime@ufsj.edu.br). 


\section{HüMANAs}

Sabe-se que a temporalidade da existência ajuda a pensar a relação do homem com o mundo. Com o propósito de transcender a visão da consciência com as coisas, Jaspers cria o conceito de englobante. Ele entende com este conceito que as diversas dimensões do real não se esgotam nas análises fenomênicas. Descobre-se assim, um pensamento que se abre à transcendência e ao problema do ser pelo reconhecimento das limitações da existência. As escolhas existenciais são expressão da liberdade humana. Karl Jaspers diz que a filosofia propicia uma independência interior porque permite que o homem se liberte dos modos fechados de pensar, de sistemas e crenças antigas. Em relação à história, Jaspers avalia que o passado é importante para compreender o presente. A história é referência para entender os problemas, no entanto, afirma ser necessário ir além dela e pensar o futuro aberto e diferente do que foi o passado. O englobante é o conceito com o qual ele trata o fundamento da realidade, isto é, as formas de transcendência que brotam da existência empírica (Daisen), consciência em geral, (espírito) e existência pessoal. Englobante é o que está além da cisão presente na consciência e é de onde tudo surge.

No segundo capítulo, o autor aprofunda a visão de Jaspers sobre a realidade. Para o filósofo, o homem vive num meio natural humanizado pela cultura. Vivendo em sociedade o homem se depara com coisas e pessoas que oferecem resistência à sua presença. $\mathrm{O}$ que resiste à sua presença no mundo é o que Jaspers denomina realidade. Para compreensão da realidade não se pode separar o homem do mundo, como sugere o método fenomenológico. Para o filósofo, o mundo de cada um é singular, no entanto os homens colaboram uns com os outros para construir uma compreensão objetiva de mundo nos moldes sugeridos pela fenomenologia de Husserl.

O mundo da natureza é objeto de estudo da ciência. Para resolver problemas práticos, o homem criou a tecnologia e a ciência, mas elas não elaboram uma explicação sobre a totalidade do real e limitam suas explicações a objetos singulares. Para se chegar à totalidade é necessário uma compreensão ampla e inter-relacionada de todos os conhecimentos humanos, além de uma metodologia diversa da ciência. No entanto, nenhuma visão da realidade, com caráter filosófico, pode prescindir das referências e do conhecimento que a ciência oferece. Quando o indivíduo apresenta uma compreensão distorcida da realidade, sem partilhar das objetividades reconhecidas pela sociedade provavelmente está em curso um transtorno psicopatológico. Para Jaspers, a consciência da realidade depende da forma como a pessoa experimenta o tempo e o espaço. Os estudos de fenomenologia indicam que a perda da consciência da realidade e da existência é uma forma de alheamento do mundo.

O conhecimento da realidade, tanto o fornecido pela ciência, como o que vem da explicação geral do mundo através da filosofia revelam os limites do existente. A realidade do homem é histórica. Isso significa que o homem é temporal, 
e é o tempo que tece sua vida. Embora ele viva no presente e tenha a noção do que de fato é real, muitas vezes encontra-se preso ao que já passou e fica inseguro quanto ao que está por vir. A experiência da realidade leva-o, portanto a considerar a transcendência. Jaspers não é religioso, mas toma a abertura ao infinito, que o Ocidente considera o problema de Deus, como uma das formas de englobante.

No terceiro capítulo, a psicologia fenomenológica de Jaspers é o assunto central. Em sua vida, o autor foi primeiro médico e psicólogo e só depois filósofo. $\mathrm{O}$ autor do livro estuda as idéias psicológicas por último, pois lhe parece que os pressupostos filosóficos são essenciais para sua compreensão. Começa-se examinando a relação entre a Filosofia e a Psicologia, pois o terapeuta precisa ter conhecimento de filosofia para orientar sua prática clínica. Em seus trabalhos de Psicologia, Karl Jaspers usa o método fenomenológico para descrever os fatos psicológicos, assegurando o caráter de cientificidade da investigação. O filósofo usa a fenomenologia para tratar os fatos psicológicos como um estrato da realidade, sem generalizar as referências para outras regiões da realidade. Para descrever o homem Jaspers diz: "o homem é um mundo". Quer dizer que a visão humana da realidade é excepcionalmente singular, e é marcada pela perspectiva que o sujeito se encontra. Jaspers se vale do método fenomenológico de Husserl, para dizer que cada existente possui um modo de ser próprio, vive a vida a seu modo e a partir dessa vivência, construirá sua compreensão de mundo.

O filósofo e psicólogo nos lembra que as dificuldades existenciais também se relacionam com as dificuldades da civilização. Olhando o homem singular é possível entender como cada um vive as suas dores psicológicas. De acordo com Jaspers, é possível analisar o homem cientificamente, no entanto, este estudo não permitirá uma compreensão completa do homem. Muito do seu mundo permanece fora dos instrumentos da ciência. A fenomenologia examina os fatos psicológicos, é um instrumento metodológico para ir ao mundo do outro e buscar compreendê-lo.

Na conclusão, Carvalho apresenta um texto autobiográfico de Jaspers e comenta sua trajetória existencial. Ele indica a importância de sua obra e também do respeito que merece o filósofo. Recorda que Jaspers, mesmo nos momentos de dificuldades se empenhou na defesa dos valores humanos. O autor também nos coloca frente à influências recebidas por Jaspers, entre as quais destaca a fenomenologia de Husserl, que muitos filósofos entendem ser um método sólido para construção da Psicologia científica. É a partir do legado de Husserl e Jaspers, que se compreende a subjetividade transcendental, expresso na clínica psicoterápica como singularidade existencial.

A obra de José Maurício de Carvalho nos coloca diante de um filósofo, cujo pensamento fenomenológico enfrenta o significado da realidade, oferecendo aos contemporâneos um sentido para o que existe e uma forma de compreender a vida. 


\section{UMANAS}

Karl Jaspers considera que a filosofia dá ao homem independência, pelo fato de proporcionar uma vida singular e meditada que pode ser boa. Ele ainda apresenta o homem como um existente, que não se separa da situação em que se encontra. Esses aspectos fazem do homem um ente independente e singular inserido no mundo, ao mesmo tempo independente e responsável por ele. É importante salientar que ao dar ênfase à responsabilidade do homem por seu destino o filósofo não deixa de falar da transcendência. Percebe-se, com o livro em questão, a importância de Karl Jaspers, tanto de sua obra científica e filosófica, como de sua vida dedicada à defesa do humanismo. O cuidado com o homem de que se ocupa o filósofo têm-se mostrado cada vez mais necessário e atual, principalmente em uma época em que o avanço tecnológico e científico têm tratado o homem como coisa, deixando de lado tudo o que não se enquadra nesta abordagem. 